\title{
ПEPIEXOMENA / CONTENTS
}

\section{TOMOE 1 / VOLUME 1

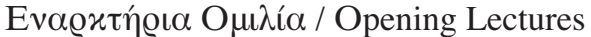

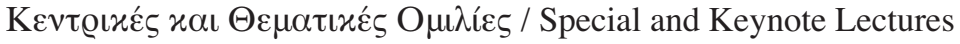

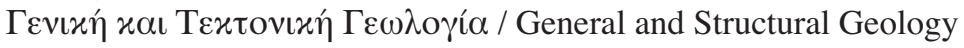

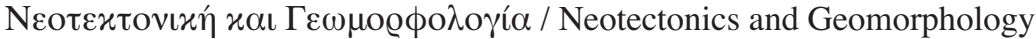

\section{ENAPKTHPIA OMIAIA / OPENING LECTURE}

Zerefos C.S.: The "Anthropocene" in the Mediterranean

\section{KENTPIKE $\Sigma$ OMIAIE $\Sigma$ / SPECIAL LECTURES}

Foscolos, A.E.: Climatic Changes: Anthropogenic Influence or Naturally Induced Phenomenon 8

Makris, J.: Geophysical studies and tectonism of the Hellenides 32

Papazachos, B.C., Karakaisis, G.F., Papazachos, C.B., Scordilis E.M.: Intermediate Term Earthquake Prediction Based on Interevent Times of Mainshocks and on Seismic Triggering 46

Rausch, R., Schüth, C., Kallioras, A.: Groundwater Resources Management in Arid Countries 69

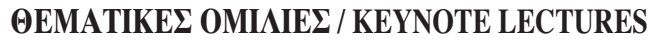

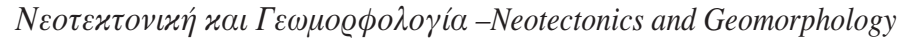

Papanikolaou, D.: Major Paleogeographic, tectonic and geodynamic changes from the last stage of the Hellenides to the actual Hellenic Arc and Trench System

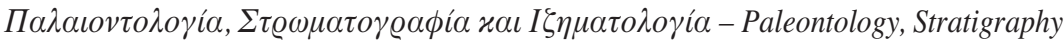
and Sedimentology

Dermitzakis, M.D.: The Status of Stratigraphy in the 21st Century 86

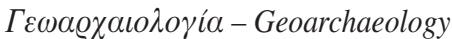

Mariolakos, I.D.: The forgotten geographical and physical - oceanographic knowledge of the Prehistoric Greeks 92

Papamarinopoulos, S.P.: Atlantis in Spain (Part I, II, III, IV, V, VI) 105

Гєஸ́толоь-Geosites

Zouros, N.: Geodiversity and Sustainable Development: Geoparks - A new challenge for Research and Education in Earth Sciences

$\Delta \iota \delta \alpha \varkappa \tau \iota \varkappa \dot{~} \tau \omega \nu \Gamma \varepsilon \omega \varepsilon \pi \iota \sigma \tau \eta \mu \omega ́ v$ - Teaching Earth Sciences

Makri, K., Pavlides, S.B., Kastanis, N.: An analysis of Geological Textbooks, at 1830-1930 169

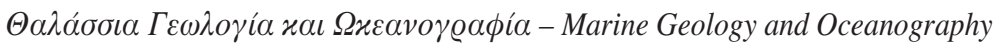

Ferentinos, G.: The contribution of Marine Geology to the Socio-economic Development of Greece: 
Marine Resources, Infrastructure, Environment Sustainability, Cultural Heritage. A brief account of the 30 years contribution of the laboratory of Marine Geology and Physical Oceanography

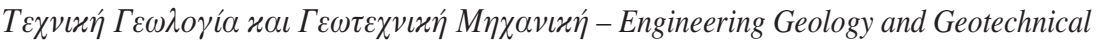
Engineering

Tsiambaos, G.: Engineering Geological Behaviour of Heterogeneous and Chaotic Rock masses 183

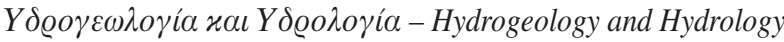

Soulios, G.: Springs (Classification, Function, Capturing)

$\sum \varepsilon \iota \sigma \mu о \lambda о \gamma i ́ \alpha-$ Seismology

Makropoulos, K.C.: Earthquakes and Preventive Measures

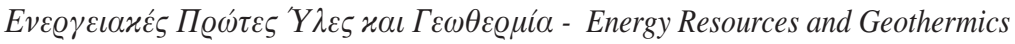

Christanis, K.: Energy Resources of Greece: Facts and Myths 224

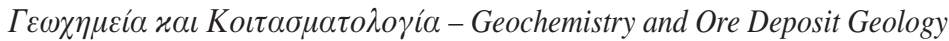

Varnavas, S.: Medical Geochemistry. A key in the Precautionary Measures against the Development of Cancer and other Diseases

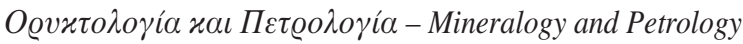

Katagas, Ch.: Wandering about Mineralogy and Petrology

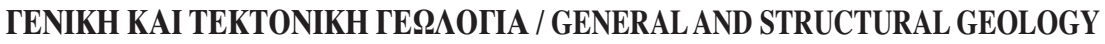

Argyriadis, I., Midoun, M., Ntontos, P.: A new interpretation of the Structure of Internal Hellenides ..... 264

Kilias, Ad., Frisch, W., Avgerinas, A., Dunkl, I., Falalakis, G., Gawlick, H-J., Mountrakis, D.:

The Pelagonian nappe pile in Northern Greece and FYROM. Structural Evolution during the Alpine

Orogeny: A new approach

Kokinou, E., Kamberis, E., Sarris, A., Tzanaki, I.: Geological and Magnetic Susceptibility Mapping of Mount Giouchta (Central Crete)

Kurz, W., Wölfler, A., Handler, R.: Cenozoic Tectonic Evolution of the Eastern Alps A reconstruction based on ${ }^{40} \mathrm{AR} /{ }^{39} \mathrm{AR}$ Mica, Zircon and Apatite Fission track and Apatite (U/TH) HE Thermochronology

Marsellos, A.E., Kidd, W.S.F., Garver, J.I., Kyriakopoulos, K.G.: Exhumation of the Hellenic Accretionary Prism - Evidence from the Fission Track Thermochronology

Migiros, G., Antoniou, Vas., Papanikolaou, I., Antoniou, Var.: Tectonic setting and deformation of the Kallidromo Mt, Central Greece

Papageorgiou, E.: Crustal Movements along the Hellenic Volcanic Arc from DGPS measurements 331

Papageorgiou, E., Tzanis, A., Sotiropoulos, P., Lagios, E.: DGPS and Magnetotelluric constrainsts on the Contemporary Tectonics of the Santorini Volcanic Complex, Greece

Papoulia, J., Makris, J.: Tectonic processes and crustal evolution on/offshore western Peloponnese derived from active and passive seismics

Spanos, D., Koukouvelas, I., Kokkalas, S., Xypolias, P.: Patterns of Ductile Deformation in Attico - Cycladic Massif 
Tselepides, V., Rondoyanni, Th.: A contribution to the Geological Structure of Chios Island,

Eastern Aegean Sea

Xypolias, P., Chatzaras, V.: The nature of Ductile deformation in the Phyllite - Quartzite unit

(External Hellenides)

\section{NEOTEKTONIKH КАI ГЕЯMOРФОАОГIA / NEOTECTONICS AND GEOMORPHOLOGY}

Caputo, R., Catalano, S., Monaco, C., Romagnoli, G., Tortorici, G., Tortorici, L.: Middle Late Quaternary Geodynamics of Crete, Southern Aegean, and Seismotectonic Implications 400

Gaki - Papanastassiou, K., Karymbalis, E., Maroukian, H.: Recent Geomorphic changes and Anthropogenic Activities in the Deltaic Plain of Pinios River in Central Greece

Gaki - Papanastassiou, K., Karymbalis, E., Maroukian, H., Tsanakas, K.: Geomorphic evolution of Western (Paliki) Kephalonia Island (Greece) during the Quaternary

Kokkalas, S.: Segmentation and Interaction of Normal Faults in Central Greece 428

Metaxas, Ch.P., Lalechos, N.S., Lalechos, S.N.: Kastoria "Blind" Active Fault: Hazardous Seismogenic Fault of the NW Greece

Mourtzas, N.D.: Sea level changes along the coast of Kea Island and Paleogeographical coastal reconstruction of Archaeological sites

Nomikou, P., Papanikolaou, D.: A comparative morphological study of the Kos - Nisyros Tilos volcanosedimentary basins

Papanikolaou, M., Papanikolaou, D., Triantaphyllou, M.: Post - Alpine Late Pliocene Middle Pleistocene uplifted Marine sequences in Zakynthos Islands

Pavlides, S., Caputo, R., Sboras, S., Chatzipetros, A., Papathanasiou, G., Valkaniotis, S.:

The Greek Catalogue of Active Faults and Database of Seismogenic Sources 486

Tranos, M.D., Mountrakis, D.M., Papazachos, C.B., Karagianni, E., Vamvakaris, D.:

Faulting deformation of the Mesohellenic Trough in the Kastoria - Nestorion Region

(Western Macedonia, Greece)

Tsanakas, K., Gaki-Papanastassiou, K., Poulos, S.E., Maroukian, H.: Geomorphology and Sedimentological processes along the coastal zone between Livanates and Agios konstantinos (N. Evoikos Gulf, Central Greece)

Vassilopoulou, S.: Morphotectonic analysis of Southern Argolis Peninsula (Greece) based on Ground and Satellite Data by GIS Development

Zygouri, V.: Probabilistic Hazard Assessment, using Arias Intensity Equation, in the eastern part of the Gulf of Corinth (Greece) 


\section{TOMOE 2 / VOLUME 2}

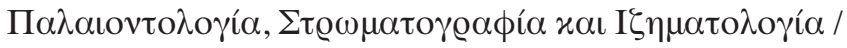

Palaeontology, Stratigraphy and Sedimentology

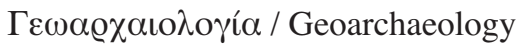

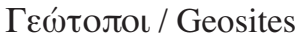

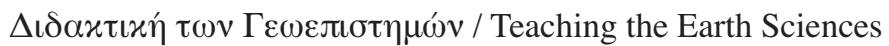

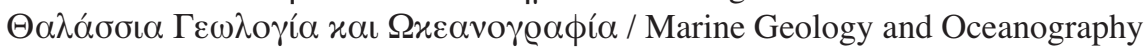

\section{ПАААІОNТОАОГІА, ЕТРЯМАТОГРАФІА КАІ ІZНМАТОАОГІА / PALAEONTOLOGY, STRATIGRAPHY AND SEDIMENTOLOGY}

\section{Anagnostoudi, Th., Papadopoulou, S., Ktenas, D., Gkadri, E., Pyliotis, I., Kokkidis, N.,}

Panagiotopoulos, V.: The Olvios, Rethis and Inachos Drainage System Evolution and Human activities influence of their future evolution

Avramidis, P., Panagiotaras, D., Papoulis, D., Kontopoulos, N.: Sedimentological and Geochemical characterization of Holocene sediments, from Alikes Lagoon, Zakynthos Island, Western Greece ........ 558

Antonarakou, A.: Plankton Biostratigraphy and Paleoclimatic implications of an Early Late Miocene sequence of Levkas Island, Ionian Sea, Greece

Bellas, S., Keupp, H.: Contribution to the late Neogene stratigraphy of the Ancient Gortys area (Southern Central Crete, Greece)

Codrea, V., Barbu, O., Jipa-Murzea, C.: Upper Cretaceous (Maastrichtian) land vertebrate diversity in Alba district (Romania)

Dimiza, M.D., Triantaphyllou, M.V.: Comparing living and Holocene coccolithophore assemblages in the Aegean marine environments)

Drinia, H., Koskeridou, E., Antonarakou, A., Tzortzaki, E.: Benthic Foraminifera associated with the zooxanthellate coral Cladocora in the Pleistocene of the Kos Island (Aegean Sea, Greece): sea level changes and palaeoenvironmental conditions

Drinia, H., Pomoni-Papaioannou, F., Tsaparas, N., Antonarakou, A.: Miocene Scleractinian corals of Gavdos Island, Southern Greece: Implications for tectonic control and sea level changes ...

Kafousia, N., Karakitsios, V., Jenkyns, H.C.: Preliminary data from the first record of the Early Toarcian oceanic anoxic event in the sediments of the Pindos Zone (Greece)

Karakitsios, V. Triantaphyllou, M. Panoussi, P.: Preliminary study on the slump structures of the Early Oligocene sediments of the Pre-Apulian zone (Antipaxos Island, North-western Greece) ...... 634

Kourkounis, S., Panagiotakopoulou, O., Zelilidis, A., Kontopoulos, N.: Texture versus distance of travel of gravels on a stream bed: a case study from four streams in NW Peloponnese, Greece

Koutsios, A., Kontopoulos, N., Kalisperi, D., Soupios, P. Avramidis, P.: Sedimentological and Geophysical observations in the Delta Plain of Selinous River, Ancient Helike, Northern Peloponnesus Greece

Kyriakopoulos, K., Karakitsios, V., Tsipoura-Vlachou, M., Barbera G., Mazzoleni, P. Puglisi, D.: Petrological characters of the Early Cretaceous Boeothian Flysch, (Central Greece) 663 
Makrodimitras, G., Stoykova, K., Vakalas, I., Zelilidis, A.: Age determination and

Palaeogeographic reconstruction of Diapondia Islands in NW Greece, based on

Calcareous Nannofossils

Maneta, V., Voudouris, P.: Quartz megacrysts in Greece: Mineralogy and Environment of Formation ..... 685

Manoutsoglou, E., Batsalas, A., Stamboliadis, E., Pantelaki, O., Vakalas, I., Zelilidis, A.:

The Auriferous submarine fans sandstones of the Ionian zone (Epirus, Greece)

Moumou, Ch., Vouvalidis, K., Pechlivanidou, S., Nikolaou, P.: The Fluvial action of the Karla basin streams in a natural and man-made environment

Pavlopoulos, A., Kamperis, E., Sotiropoulos, S., Triantaphyllou, M.: Tectonosedimentary significance of the Messinia conglomerates (SW Peloponnese, Greece)

Photiades, A., Pomoni-Papaioannou, F.A., Kostopoulou, V.: Correlation of Late Triassic and Early Jurassic Lofer - type carbonates from the Peloponnesus peninsula, Greece

Sigalos, G., Loukaidi, V., Dasaklis, S., Alexouli-Livaditi, A.: Assessment of the Quantity of the material transported downstream of Sperchios River, Central Greece

Svana, K., Iliopoulos, G., Fassoulas, C.: New Sirenian findings from Crete Island 746

Triantaphyllou, M.V.: Calcareous nannofossil Biostratigraphy of Langhian deposits in Lefkas (Ionian Islands)

Triantaphyllou, M.V., Antonarakou, A., Drinia, H., Dimiza M.D., Kontakiotis, G., Tsolakis, E.

Theodorou, G.: High resolution Biostratigraphy and Paleoecology of the Early Pliocene succession of Pissouri Basin (Cyprus Island)

Zambetakis - Lekkas, A.: On the occurrence of primitive Orbitoides species in Gavrovo Tripolitza platform (Mainalon Mountain, Peloponnesus, Greece)

Zidianakis, G., Iliopoulos, G., Fassoulas, C.: A new late Miocene plant assemblage from Messara Basin (Crete, Greece)

Zoumpoulis, E., Pomoni-Papaioannou, F., Zelilidis, A.: Studying in the Paxos zone the carbonate depositional environment changes during Upper Cretaceous, in Sami area of Kefallinia Island, Greece 793

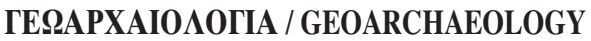

Economou, G., Kougemitrou, I., Perraki, M., Konstantinidi-Syvridi, E., Smith, D.C.:

A Mineralogical study of some Mycenaean Seals employing Mobile Raman Microscopy

Katsonopoulou, D.: Earth Science Applications in the field of Archaeology: the Helike example

Mariolakos, I.,Theocharis, D.: Geomythological approach of Asopos River (Aegina, Greece)

Mariolakos, I., Nikolopoulos, V., Bantekas, I., Palyvos, N.: Oracles on faults: a probable location of a "lost" oracle of Apollo near Oroviai (Northern Euboea Island, Greece) viewed in its Geological and Geomorphological context

Melfos, V., Voudouris, P., Papadopoulou, L., Sdrolia, S., Helly, B.: Mineralogical, Petrographic and stable isotopic study of Ancient white marble quarries in Thessaly, Greece - II. Chasanbali, Tempi, Atrax, Tisaion Mountain

Rathossi, C., Pontikes, Y., Tsolis-Katagas, P.: Mineralogical differences between ancient sherds 
and experimental ceramics: Indices for Firing conditions and Post - burial alteration 856

Stiros, S., Kontogianni, V.: Selection of the path of the Eupalinos aqueduct at Ancient Samos on the basis of Geodetic and Geological / Geotechnical criteria 866

\section{ГEQTOIOI / GEOSITES}

Antonelou, A., Tsikouras, B., Papoulis, D., Hatzipanagiotou, K.: Investigation of the formation of speleothems in the Agios Georgios Cave, Kilkis (N. Greece)

Dotsika, E., Psomiadis, D., Zanchetta, G., Spyropoulos, N., Leone, G., Tzavidopoulos, I., Poutoukis, D.: Pleistocene Palaeoclimatic evolution from Agios Georgios Cave speleothem (Kilkis, N. Greece) 886

Fassoulas, C., Zouros, N.: Evaluating the influence of Greek Geoparks to the local communities 896

Haidarlis, M., Sifakis, A., Brachou C.: Geoconservation legal status and Geopark establishment in Greece

Illiopoulos, G., Eikamp, H., Fassoulas, C.: A new Late Pleistocene mammal locality from Western Crete

Theodosiou, Ir.: Designation of Geosites - Proposals for Geoparks in Greece 926

Theodosiou, Ir., Athanassouli, E., Epitropou, N., Janikian, Z., Kossiaris, G., Michail, K., Nicolaou, E., Papanikos, D., Pashos, P., Pavlidou, S., Vougioukalakis, G.: Geotrails in Greece ...... 939

Vaxevanopoulos, M., Melfos, V.: Hypogenic features in Maronia Cave, Thrace, Greece. Evidence from morphologies and fluid inclusions

Zisi, N., Dotsika, E., Tsoukala, E., Giannakopoulos, A., Psomiadis, D.: Palaeoclimatic evolution in Loutra Arideas Cave (Almopia Speleopark, Macedonia, N. Greece) by stable isotopic analysis of fossil bear bones and teeth

Zouros, N., Valiakos, I.: Geoparks management and assessment 965

\section{$\Delta \mathrm{I} \Delta \mathrm{AKTIKH} \mathrm{T \Omega N} \mathrm{\Gamma EQEII \Sigma THM \Omega N} \mathrm{/} \mathrm{TEACHING} \mathrm{EARTH} \mathrm{SCIENCES}$}

Fermeli, G., Dermitzakis, M.: The contribution of Museums' digitalized Palaeontological collections to the scientific literacy of compulsory education students: the case of an interactive multimedia production of the Palaeontological and Geological Museum of the University of Athens

Fermeli, G., Vitsas, T., Foundas, P., Sokos, E., Alexandropoulou, S., Papatheodoropoulos, P., Germenis, N., Nikolaidis, A., Zevgitis, T.: The use of Educational seismographs in the Seismology School Network "EGELADOS"

Katrivanos, D.E., Makri, K.: Perception of first-year geology students on the Tectonic Plates Theory .... 999

Kritikou, S., Malegiannaki, I.: Following the traces of Naxian emery - an implementation of environmental education in geodidactics

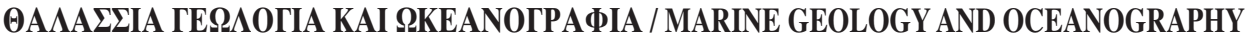

Iatrou, M., Papatheodorou, G., Geraga, M., Ferentinos, G.: The study of Heavy Metal concentrations in the Red Mud deposits at the Gulf of Corinth, using multivariate techniques 1018 
Lycourghiotis, S., Stiros, S.: Sea surface topography in the Gulf of Patras and the Southern Ionian Sea using GPS

Perissoratis, C., Ioakim, Chr.: Research projects to study the Sea floor and Sub-bottom sediments funded by the recent European Commission Framework Programs: The IGME Participation 1035

Sakellariou, D., Fountoulis, I., Lykousis, V.: Evidence of cold seeping in Plio-Pleistocene sediments of SE Peloponese: The fossil carbonate chimneys of Neapolis Region

Sakellariou, D., Sigurdsson, H., Alexandri, M., Carey, S., Rousakis, G., Nomikou, P., Georgiou P., Ballas, D.: Active tectonics in the Hellenic Volcanic Arc: The Kolumbo submarine volcanic zone 1056

Thomopoulos, K., Geraga, M., Fakiris, E., Papatheodorou, G., Ferentinos, G.: Palaeoclimatic and Palaeoceanographic evolution of the Mediterranean Sea over the last 18ka

Xeidakis, G., Georgoulas, A., Kotsovinos, N., Delimani, P., Varaggouli, E.: Environmental Degradation of the coastal zone of the West part of Nestos River Delta, N. Greece

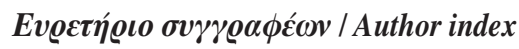
1085

TOMOE 3 / VOLUME 3

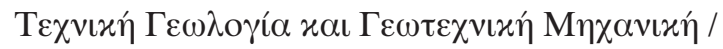

Engineering geology and Geotechnical Engineering

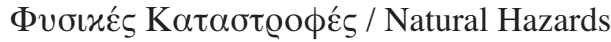

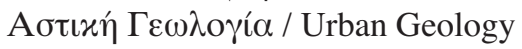

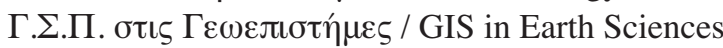

\section{TEXNIKH ГE $\Lambda 0$ ОIA KAI ГEQTEXNIKH MHXANIKH / ENGINEERING GEOLOGY AND GEOTECHNICAL ENGINEERING}

Angelopoulos, A., Soulis, V.J., Malandraki, V.: Geological and geotechnical behaviour of Evinos Dam following the impoundment

Antoniou, A.A., Tsiambaos, G.: Engineering geological aspects for the microzonation of the city of Volos, Greece

Chatziangelou, M., Thomopoulos, Ach., Christaras, B.: Excavation data and failure investigation along tunnel of Symbol Mountain

Christaras, B., Papathanassiou G., Vouvalidis, K., Pavlides, S.: Preliminary results regarding the rock falls of December 17,2009 at Tempi, Greece

Christaras, B., Syrides, G., Papathanassiou, G., Chatzipetros, A., Mavromatis, T., Pavlides, Sp.: Evaluating the triggering factors of the rock falls of $16^{\text {th }}$ and $21^{\text {st }}$ December 2009 in Nea Fokea, Chalkidiki, Norterh Greece

Depountis, N., Lainas, S., Pyrgakis, D., Sabatakakis, N., Koukis, G.: Engineering Geological and geotechnical investigation of landslide events in wildfire affected areas of Ilia Prefecture, Western Greece 
Diasakos, N., Amerikanos, P., Tryfonas, G., Vagiotou, E., Baltzois, V., Bloukas, S., Tagkas, Th., Malandrakis, E., Poulakis, N., Kalogerogiannis, G., Tsirigotis, N.: Tunnel excavation in clayey-marly formations: The case of Kallidromo Tunnel

Hagiou, E., Konstantopoulou, G.: Environmental planning of abandoned Quarries rehabilitation A methodology

Karagianni, A., Karoutzos, G., Ktena, S., Vagenas, N., Vlachopoulos, I., , Sabatakakis, N., Koukis, G.: Elastic Properties of Rocks

Kouki,A.: Mineralogical composition and fabric as related to the mechanical behavior of the fine - grained Plio - Pleistocene sediments of Achaia, Greece

Kouki, A., Rozos, D.: The fine - grained Plio - Pleistocene deposits in Achaia - Greece and their distinction in characteristic geotechnical units

Kouki, A., Rozos, D.: Engineering - Geotechnical conditions in Patras ring road wider area, Greece. Compilation of the relevant map at scale of 1:5000

Kozyreva, E.A., Khak, V.A.: The anthropogenic changes in the Geological Environment in the South of East Siberia

Kynigalaki, M., Kanaris, D., Nikolaou, N., Kontogianni, V.: Buildings' damage at Horemi Village, Arkadia, Greece: evaluation of the Geotechnical conditions at shallow depths

Lainas, S., Koulouris, S., Vagenas, S., Depountis, N., Sabatakakis, N., Koukis, G.: Earthquake-induced rockfalls in Santomeri Village, Western Greece

Loupasakis, C., Rozos, D.: Land subsidence induced by the overexploitation of the aquifers in Kalochori village - new approach by means of the computational geotechnical engineering

Loupasakis, C., Spanou, N., Kanaris, D., Exioglou, D., Georgakopoulos, A.: Geotechnical investigation of the rock slope stability problems occurred at the foundations of the coastal byzantine wall of Kavala city, Greece

Marinos, P.V.: Engineering geological behaviour of rock masses in underground excavations 1238

Marinos, P.V.: New proposed GSI classification charts for weak or complex rock masses

Marinos, P.V., Tsiambaos, G.: Strength and deformability of specific sedimentary and ophiolithic rocks

Moraiti, E., Christaras, B., Brauer, R.: Landslide in Nachterstedt of Germany

Mourtzas, N., Gkiolas, A.: Tunneling in ophiolithic series formations: Tunnels of the new high-speed railway double track line - section Lianokladi - Domokos

Mourtzas, N.D., Symeonidis, K., Passas, N., Alkalais, E., Kolaiti, E.: Slope stabilization on Chalkoutsi - Dilesi road, at Pigadakia location, Attica Prefecture

Parcharidis, I., Foumelis, M., Kourkouli, P.: Slope instability monitoring by space-borne SAR interferometry: Preliminary results from Panachaico Mountain (Western Greece)

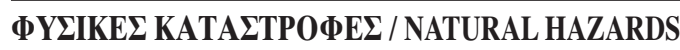

Bizoura, A., Lykoudi, E., Spyridonos, E., Manoutsoglou, E.: Assessment of the vulnerability degree of different lithological formations in the catchment area of Agia Eirini Gorge, Western Crete 
Diakakis, M.: Flood history analysis and its contribution to flood hazard assessment. The case of Marathonas, Greece

Gournelos, T., Nastos, P.T., Chalkias, D., Tsagas, D., Theodorou, D.: Landslide movements related to precipitation. Analysis of a statistical sample from the Greek area

Kadetova, A.V., Kozireva, E.A.: The potential natural hazards to be considered in the design and exploitation of the aerial rope-way in the "Gora Sobolinaya" mountain-skiing resort (Southern Pribaikalia, Russia)

Kalantzi, F., Doutsou, I., Koukouvelas, I.: Historical landslides in the Prefecture of Ioannina - collection and analysis of data

Lekkas, E.: Macroseismicity and geological effects of the Wenchuan earthquake (Ms 8.0r 12 May 2008), Sichuan, China: Macro-distribution and comparison of EMS 1998 and $\mathrm{ESI}_{2007}$ intensities

Papathanassiou, G., Pavlides, S.: Probabilistic evaluation of liquefaction-induced ground failures triggered by seismic loading in urban environment; case studies from Greece

Papathanassiou, G., Valkaniotis, S., Chatzipetros, Al., Pavlides S.: Liquefaction susceptibility map of Greece

Poyiadji, E., Nikolaou,N., Karmis, P.: Ground failure due to Gypsum dissolution

Rozos, D., Lykoudi, E. , Tsangaratos, P., Markantonis, K., Georgiadis, P. , Rondoyanni, Th., Leivaditi, A., Kyrousis, I.: Evaluation of soil erosion and susceptibility to landslide manifestation as a consequence of wildfire events affected the Zacharo municipality, Peloponnesus, Greece

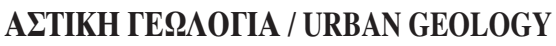

Apostolidis, Em., Koutsouveli, An.: Engineering geological mapping in the urban and suburban region of Nafplion city (Argolis, Greece)

Georgiou, Ch., Galanakis, D.: Neotectonic study of urban and suburban Nafplio area (Argolida-Greece)

Karastathis, V.K., Karmis, P., Novikova, T., Roumelioti, Z., Gerolymatou, E., Papanastassiou, D., Liakopoulos, S., Giannoulopoulos, P., Tsombos, P., Papadopoulos, G. A.: Liquefaction risk assessment by the use of Geophysical techniques: The test area of Nafplion city, Greece

Karmis, P.D., Giannoulopoulos, P., Tsombos, P.: Geophysical investigations at Nafplion city, Greece. Hydrogeological implications

Koukoulis, A., Karageorgiou, D.E.: Radon: Geoinformation for the planning of urban - suburban regions. The case of Nafplion city, Greece

Loupasakis, C., Galanakis, D., Rozos, D.: Rock slope stability problems in natural sightseeing areas - an example from Arvanitia, Nafplio, Greece

Mitropoulos, D., Zananiri, I.: Upper Quaternary evolution of the Northern Argolis Gulf, Nafplio area

Nikolakopoulos, K., Tsompos, P.: Remote sensing applications in the frame of "Urban Geology" project 
Photiades, A.: Geological contribution to the tectono- stratigraphy of the Nafplion area (NW Argolis, Greece)

Sabatakakis, P., Koukis, G.: Aqueous environment and effects on the civil areas:

The case of Nafplio

Tassiou, S.,Vassiliades, E.: Geochemical study of the urban and suburban area of Nafplion city, Argolidha Prefecture, Hellas

Tsombos, P.I., Zervakou, A.D.: The "Urban Geology" project of IGME: The case study of Nafplio, Argolis Prefecture, Greece

Zananiri, I., Chiotis, E., Tsombos, P., Hademenos, V., Zervakou, A.: Geoarchaeological studies in urban and suburban areas of the Argolis Prefecture

Zananiri, I., Zervakou, A., Tsombos, P., Chiotis, E.: Visualization of datasets from urban geology studies using Google Earth: The case study of Nafplio, Argolis Prefecture

Zervakou, A.D., Tsombos, P.I.: GIS in urban geology: The case study of Nafplio, Argolis Prefecture, Greece

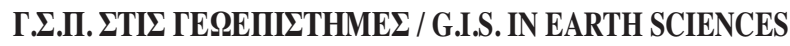

Bathrellos, G.D., Skilodimou, H.D., Chousianitis, K.G.: Soil erosion assessment in Southern Evia Island using USLE and GIS

Golubović Deliganni, M., Parcharidis, I., Pavlopoulos, K.: Karstic landscape study based on Remote Sensing Data: the case of Ksiromero region, Aitoloakarnania - Western Greece

Ilia, I., Tsangaratos, P., Koumantakis, I., Rozos, D.: Application of a Bayesian approach in GIS based model for evaluating landslide susceptibility. Case study Kimi area, Euboea, Greece

Karageorgiou, M.M.D., Karymbalis, E., Karageorgiou, D.E.: The use of the Geographical Information Systems (G.I.S.) in the geological - mineralogical mapping of the Paranesti area

Sboras, S., Ganas, A., Pavlides, S. : Morphotectonic analysis of the neotectonic and active faults of Beotia (Central Greece), using G.I.S. techniques

Kynigalaki, M., Nikolaou, N., Karfakis, J., Koutsouveli, An., Poyiadji, El., Pyrgiotis, L., Konstantopoulou, G., Bellas, M., Apostolidis, Em., Loupasakis, K., Spanou, N., Sabatakakis, N., Koukis, G.: Digital engineering geological map of the Athens Prefecture area and related Database Management System

Nikolakopoulos, K., Gioti, Ev., Skianis, G., Vaiopoulos, D.: Ameliorating the Spatial Resolution of Hyperion Hyperspectral Data. The case of Antiparos Island

Rozos, D., Bathrellos, D.G., Skilodimou, D.H.: Landslide susceptibility mapping of the Northeastern part of Achaia Prefecture using Analytical Hierarchical Process and GIS techniques

Skianis, G.Aim., Gournelos, Th., Vaiopoulos, D., Nikolakopoulos, K.: A study of the performance of the Modified Transformed Vegetation Index MTVI

Tsangaratos, P., Koumantakis, I., Rozos, D.: GIS-Based application for geotechnical data managing 


\section{TOMOE 4 / VOLUME 4}

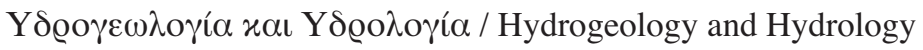

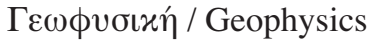

$\Sigma \varepsilon \iota \sigma \mu о \lambda о \gamma i ́ \alpha$ / Seismology

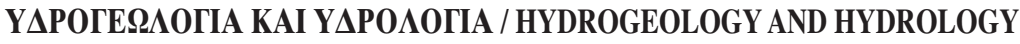

Christaras, B.: Could water co-management contribute to Peace, in Middle East? 1672

Christoforidou, P., Panagopoulos, A., Voudouris, K.: Towards a new procedure to set up groundwater threshold values in accordance with the previsions of the EC Directive 2006/118: A case study from Achaia and Corinthia (Greece)

Dimitrakopoulos, D.,Vassiliou, E., Tsangaratos, P., Ilia, I.: Environmental management of mine water, considering European Water Legislation. Case study of Megalopolis mines

Gkiougkis, I., Mwila, G., Pliakas, F., Kallioras, A., Diamantis, I.: Hydrogeological assessment of groundwater degradation at the Eastern Nestos river delta, N.E. Greece

Karalemas, N., Lekkas, S.: Operational mechanism of karst spring "Logaras", near the village "Skortsinou", Arcadia, (Peloponnesus)

Karapanos, E., Burgess, W., Lambrakis, N.: Groundwater flow modelling of the alluvial aquifer in the Mouria area, SW Greece

Katsanou, K., Stratikopoulos, K., Zagana, E. Lambrakis, N.: Radon changes along main faults in the broader Aigion region, NW Peloponnese

Kelepertzis, E., Argyraki, A., Daftsis, E., Ballas, D.: Quality characteristics of surface waters at Asprolakkas River Basin, N.E. Chalkidiki, Greece

Koukidou, I., Panagopoulos, A.: Application of feflow for the simulation of groundwater flow at the Tirnavos (Central Greece) alluvial basin aquifer system

Kounis, G.D., Kounis, K.G.: Infiltration, effective porosity, transmissibility and critical yield of water wells in the carbonate fissured aquifers of Attica - A contribution to the regional and managerial hydrogeology

Kounis, G.D., Kounis, K.G.: Relationship between the transmissibility of the "Athens Schists" and the percentage of their competent rock component

Maramathas, A., Gialamas, J., Pambuku, A., Beshku, H., Vako, E.: Brackish karst springs simulation with "modkarst" model under not enough data conditions (the case of the "Potami" spring at Himara Albania)

Mariolakos, I., Spyridonos, E.: Remarks on the karstification in the wider area of the Upper Messinia closed hydrogeological basin (SW Peloponnesus, Greece)

Matiatos, I., Alexopoulos, A., Zouridakis, N.: Use of stable isotopes in the determination of the mean altitude of recharge and the investiagation of function mechanism of spring waters in Argolis Peninsula (Greece)

Mertzanides, Y., Economou, N., Hamdan, H., Vafidis, A.: Imaging sea water intrusion in coastal 
zone of Kavala (N. Greece) with electrical resistivity tomography

Mertzanides, Y., Ziannos, V., Tsobanoglou, C., Kosmidis, E.: Telemetry network for monitoring quality of irrigation water in Kavala (N. Greece)

Nikas, K., Antonakos, A., Kallergis, G., Kounis, G.: International hydrogeological map of Europe: sheet D6 "Athina"

Papafotiou, A., Schütz, C., Lehmann, P., Vontobel, P., Or, D., Neuweiler, I.: Measurement of preferential flow during infiltration and evaporation in porous media

Raco, B., Dotsika, E., Psomiadis, D., Doveri, M., Lelli, M., Zisi, N., Papakonstantinou, K., Lazaridis, A.: Geochemical investigation of aquifer pollution from waste management. The case of Komotini landfill (Greece)

Rozos, D., Sideri, D., Loupasakis, C.Apostolidis, E.: Land subsidence due to excessive ground water withdrawal. A case study from Stavros - Farsala site, West Thessaly Greece

Skordas, K., Tziritis, E., Kelepertsis, A.: Groundwater quality of the hydrological basin of Amyros River, Agia area Thessaly, Greece

Stamatis, G.: Groundwater quality of the Ag. Paraskevi/Tempi valley karstic springs - application of a tracing test for research of the microbial pollution (Kato Olympos/NE Thessaly)

Zagana, E., Lemesios, I., Charalambopoulos, S., Katsanou, K., Stamatis, G., Lambrakis, N.: Environmental - hydrogeological investigations on the clay deposits in the broad area of Mesologgi - Aitoliko lagoons

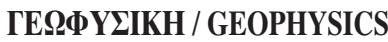

Aidona, E., Kondopoulou, D., Alexandrou, M., Ioannidis, N.: Archaeomagnetic studies in Kilns from N. Greece

Alexopoulos, J.D., Dilalos, S.: Geophysical research for geological structure determination in the region of South Mesogheia (Attica)

Arvanitis, A.A., Stampolidis, A.D., Tsokas, G.N.: Contribution of geophysical methods to the investigation of geothermal conditions in the Southwestern part of the Strymon Basin (Macedonia, Northern Greece)

Chailas, S., Tzanis, A., Kranis, H., Karmis, P.: Compilation of a unified and homogeneous aeromagnetic map of the Greek mainland

Skarlatoudis, A.A., Papazachos, C.B.: Implementation of a non-splitting formulation of perfectly matched layer in a $3 \mathrm{D}-4^{\text {th }}$ order staggered-grid velocity-stress finite-difference scheme

Tzanis, A.: A Matlab program for the analysis and interpretation of transient electromagnetic sounding data

Vargemezis, G., Fikos, I.: Large scale vertical electrical soundings survey in Anthemountas River Basin for evaluating hydraulic communication between sub basin aquifers

Vargemezis, G., Tsourlos, P., Mertzanides, I.: Contribution of deep electrical resistivity tomography technique to hydrogeological studies: Cases from areas in Kavala (North Greece)

Zananiri, I., Kondopoulou, D., Spassov, S.: The application of environmental magnetism techniques for pollution assessment in urban and suburban areas in Greece: State of the art and case studies 


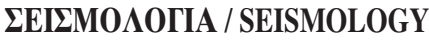

Adamaki, A.K., Tsaklidis, G.M., Papadimitriou, E.E., Karakostas, V.G.: Evidence for induced seismicity following the 2001 Skyros mainshock

Astiopoulos, A.C., Papadimitriou, E., Karakostas, V., Gospodinov, D., Drakatos, G.: Seismicity changes detection during the seismic sequences evolution as evidence of stress changes

Chousianitis, K., Agalos, A., Papadimitriou, P., Lagios, E., Makropoulos, K.: Source parameters of moderate and strong earthquakes in the broader area of Zakynthos Island (W. Greece) from regional and teleseismic digital recordings

Kapetanidis, V., Papadimitriou, P., Makropoulos, K.: A cross-correlation technique for relocation of seismicity in the Western Corinth Rift

Karakaisis, G.F., Papazachos, C.B., Scordilis, E.M.: Seismic sources and main seismic faults in the Aegean and surrounding area

Karakonstantis, A., Papadimitriou, P.: Earthquake relocation in Greece using a unified and homogenized seismological catalogue

Karakostas, V.G., Papadimitriou, E.E., Karamanos, Ch.K. Kementzetzidou, D. A.:

Microseismicity and seismotectonic properties of the Lefkada - Kefalonia seismic zone

Karakostas, V.G., Papadimitriou, E. E., Tranos, M.D., Papazachos, C.B.: Active seismotectonic structures in the area of Chios Island, North Aegean Sea, revealed from microseismicity and fault plane solutions

Karamanos, Ch.K., Karakostas, V.G., Seeber, L., Papadimitriou, E.E., Kilias, A.A.: Recent seismic activity in Central Greece revealing local seismotectonic properties

Kaviris, G., Papadimitriou, P., Makropoulos, K.: Anisotropy study of the February 4th 2008 swarm in NW Peloponnesus (Greece)

Leptokaropoulos, K.M., Papadimitriou, E.E., Orlecka-Sikora, B., Karakostas, V.G.:

Seismicity rate changes in association with time dependent stress transfer in the region of Northern Aegean Sea, Greece

Moshou, A., Papadimitriou, P., Makropoulos, K.: Moment tensor determination using a new waveform inversion technique

Paradisopoulou, P.M., Papadimitriou, E.E., Karakostas, V.G., Lasocki, S., Mirek, J., Kilias, A.: Influence of stress transfer in probability estimates of $M \geq 6.5$ earthquakes in Greece and surrounding areas

Popandopoulos, G., Baskoutas, I.: Space regularity manifestation of the temporal variation of seismic parameters: Possibility for the strong seismic activity assessment

Roumelioti, Z., Kiratzi, A.: Incorporating different source rupture characteristics into simulations of strong ground motion from the 1867, M7.0 earthquake on the Island of Lesvos

(NE Aegean Sea, Greece)

Roumelioti, Z., Kiratzi, A.: Moderate magnitude earthquake sequences in Central Greece (for the year 2008)

Scordilis, E.M.: Correlations of the mean time and mean magnitude of accelerating preshocks with the origin time and magnitude of the mainshock 
Segou, M., Voulgaris, N., Makropoulos, K.: On the sensitivity of ground motion prediction equations in Greece

Serpetsidaki, A., Sokos, E., Tselentis, G-A.: Study of the $2^{\text {nd }}$ December 2002 Vartholomio earthquake (Western Peloponnese), M5.5 aftershock sequence

Sokos, E., Pikoulis, V.E., Psarakis, E.Z., Lois, A.: The April 2007 swarm in Trichonis Lake using data from a microseismic network

Tsapanos, T.M., Koravos, G.Ch., Plessa, A., Vythoulkas, N.K., Pitsonis, I.S.: Decay parameters of aftershock sequences globally distributed

Votsi, I., Limnios, N., Tsaklidis, G., Papadimitriou, E.: Semi-Markov models for seismic hazard assessment in certain areas of Greece 2200

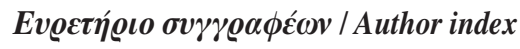
2211

TOMOE 5 / VOLUME 5

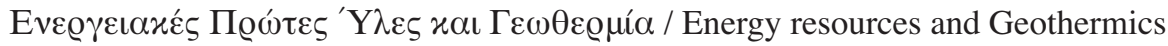

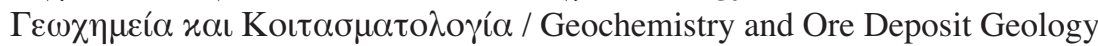

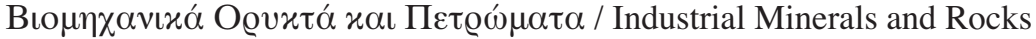

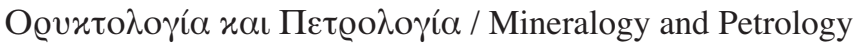

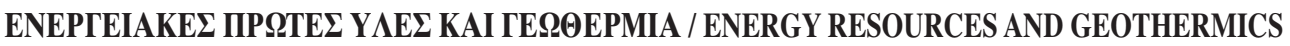

Fotopoulou, M., Siavalas, G., İnaner, H., Katsanou, K., Lambrakis, N., Christanis, K.:

Combustion and leaching behavior of trace elements in lignite and combustion by products from the Muğla basin, SW Turkey 2218

Karageorgiou, D.E., Metaxas, A., Dimitriou, D., Arapogiannis, E., Varvarousis, G.: Contribution of lignite in the Greek economy

Karageorgiou, D.E., Metaxas, A., Karageorgiou, M.M.D., Papanikolaou, G., Georgakopoulos, A.N., Vrettos, K.: Development of lignite in Crete. Comparison of basins, possibilities of exploitation 2236

Kolios, N., Arvanitis, A., Karydakis, G., Koutsinos, S.: Geothermal drilling activity in the Akropotamos Area (Macedonia, Northern Greece)

Mertzanides, Y., Kargiotis, E., Mitropoulos, A.: Geological and geophysical data of "Epsilon" field in Prinos oil basin

Metaxas, A., Varvarousis, G., Karydakis, Gr., Dotsika, E., Papanikolaou, G.: Geothermic status of Thermopylae - Anthili area in Fthiotida Prefecture

Metaxas, A., Georgakopoulos, A.N., Karageorgiou, D.M.M., Papanikolaou, G., Karageorgiou, E.D.: $\mathrm{CO}_{2}$ Content of Greek lignite: the case of Proastio Lignite deposit in Ptolemais Basin, Northern Greece

Oikonomopoulos, I., Perraki, Th., Tougiannidis, N.: FTIR study of two different lignite lithotypes from Neocene Achlada lignite deposits in NW Greece 
Papanicolaou, C., Triantafyllou, G., Pasadakis, N., Foscolos, A.E.: Adsorption of phenols from olive oil mill wastewater as well as $\mathrm{n}$ and $\mathrm{p}$ from a simulated city wastewater liquid on activated Greek lignites

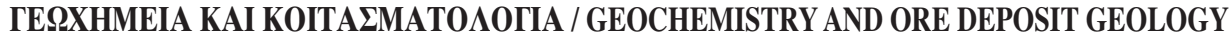

Alexandratos, V.G., Behrends, T., Van Cappellen, P.: The influence of reductive dissolution of iron oxides by $\mathrm{S}(-\mathrm{II})$ on uranium mobility 2310

Argyraki, A., Petrakaki, N.: Heterogeneity in heavy metal concentrations in the soil of a firing range area at Kesariani, Athens, Greece

D’ Alessandro, W., Brusca, L., Martelli, M., Rizzo, A., Kyriakopoulos, K.: Geochemical characterization of natural gas manifestations in Greece

Demetriades, A., Birke, M., Locutura, J., Bel-lan, A.B., Duris, M., EuroGeoSurveys Geochemistry Expert Group: Urban geochemical studies in Europe

Demetriades, A., Reimann, C., Birke, M., Salminen, R., De Vos, W., Tarvainen, T., EuroGeoSurveys Geochemistry Expert Group: Geochemical Atlases of Europe produced by the EuroGeoSurveys Geochemistry Expert Group: State of progress and potential uses

Kyriakopoulos, G.K.: Natural degassing of carbon dioxide and hydrogen sulphide and its environmental impact at Milos Island, Greece

Papastergios, G., Filippidis, A., Fernandez-Turiel, J.L., Gimeno, D., Sikalidis, C.: Natural and anthropogenic effects on the soil geochemistry of Kavala Area, Northern Greece

Psomiadis, D., Dotsika, E., Albanakis, K., Zisi, N., Poutoukis, D., Lazaridis, A.: Comparison of sampling techniques for isotopic analysis of shallow marine carbonates

Serelis, K.G., Kafkala, I.G., Parpodis, K., Lazaris, S.: Anthropogenic and Geogenic contamination due to heavy metals in the vast area of Vari, Attica

Stefanova, M., Marinov, S.P.: Organic geochemistry of humic acids from a Neogene lignite sample, Bulgaria

Tombros, S.F., St. Seymour, K., Spry, P.G., Bonsall, T.A.: The isotopic signature of the mineralizing fluid of the Lavrion carbonate-replacement $\mathrm{Pb}-\mathrm{Zn}-\mathrm{Ag}$ district

Triantafyllidis, S., Skarpelis, N.: Geochemical investigation and modelling of an acid pit lake from a high sulfidation ore deposit: Kirki, NE Greece

\section{BIOMHXANIKA OPYKTA KAI IIETPQMATA / INDUSTRIAL MINERALS AND ROCKS}

Anagnostou, Ch.: Bauxite resource exploitation in Greece vs sustainability

Arvanitidis, N.D.: New metallogenetic concepts and sustainability perspectives for non-energy metallic minerals in Central Macedonia, Greece

Fadda, S., Fiori, M., Pretti, S., Valera, P.: Volcanic - sedimentary metal deposition in Paleomargin environment: A " Protore " occurrence in Central Sardinia (Italy)

Kitsopoulos, K.: Immobile trace elements discrimination diagramms with zeolitized volcaniclastics from the Evros - Thrace - Rhodope volcanic terrain 
Lampropoulou, P., Tzevelekou, Th., Papamantellos, D., Stivanakis, V., Papaefthymiou, S.:

Human interferences to the environment, consequences and care

Laskaridis, K., Patronis, M.: "Karystía líthos": a timeless structural ornamental stone 2475

Leontakianakos, G., Baziotis, I., Ekonomou, G., Delagrammatikas, G., Galbenis, C.T., Tsimas, S.: A Case study of different limestones during quick lime and slaked-lime production 2485

Manoutsoglou, E., Panagopoulos, G., Spyridonos, E., Georgiou, A.: Methodology for optimal determination of new drilling program in an active open pit: Example from an active sulfate open pit in Altsi, Lasithi Prefecture, Eastern Crete

Mpalatsas, I., Rigopoulos, I., Tsikouras, B., Hatzipanagiotou, K.: Suitability assessment of Cretaceous limestones from Thermo (Aitoloakarnania, Western Greece) for their use as base and sub-base aggregates in road-construction

Papastamatiou, D., Skarpelis, N., Argyraki, A.: Air quality in mining areas: The case of Stratoni, Chalkidiki, Greece

\section{OPYKTO $\Lambda$ OГIA KAI ПЕTPO $\Lambda$ OГIA / MINERALOGY AND PETROLOGY}

Baziotis, I., Mposkos, E.: Geochemistry and tectonic setting of eclogite protoliths from Kechros Complex in East Rhodope (N.E. Greece)

Bourliva, A., Michailidis, K., Sikalidis, C., Filippidis, A., Apostolidis, N.: Municipal wastewater treatment with bentonite from Milos Island, Greece

Bourouni, P., Tsikouras, B., Hatzipanagiotou, K.: Petrological investigation of carbonate rocks from the Ionian Zone (Etoloakarnania, Western Greece)

Christidis, G.E., Skarpelis, N.: Clay mineralogy of the sedimentary iron-nickel ore of Agios Ioannis, NE Boeotia: new data and implication for diagenetic modifications

Christidis, G.E., Katsiki, P., Pratikakis, A., Kacandes, G.: Rheological properties of PalygorskiteSmectite suspensions from the Ventzia Basin, W. Macedonia, Greece

Christidis, G.E., Perdikatsis, V,Apostolaki, Ch.: Mineralogy of the Saharan Aeolian Dust in Crete: Examples from the period 2004-2009

Çina, A.: Mineralogy of chromitite, Bulqiza ultramafic massif, Albanian ophiolitic complex

Fadda, S., Fiori, M., Pretti, S., Valera, P.: Manganese mineralisations at the base of Miocene sediments in Northern Sardinia (Italy)

Filippidis, A., Papastergios, G., Apostolidis, N., Filippidis, S., Paragios, I., Sikalidis, C.: Purification of urban wastewaters by Hellenic natural Zeolite

Georgiadis, I.K., Koronaios, A., Tsirambides, A., Stamatakis, M.: Textural and petrological study of modern sands from the Vertiskos Unit of Serbomacedonian Massif (Macedonia, Greece)

Karipi, S., Tsikouras, B., Rigopoulos, I., Hatzipanagiotou, K., Pomonis, P.: Insights into hydrothermal activity in the Iti Ophiolite (Central Greece)

Kitsopoulos, K.: Magma generation and mixing in the earliest volcanic centre of Santorini (Akrotiri Peninsula). Mineral chemistry evidence from the Akrotiri Pyroclastics

Koutsopoulou, E., Tsolis-Katagas, P., Papoulis, D.: Heavy metals in stream sediments affected by a landfill and associated impact on groundwater quality 
Lykakis, N. Kilias, S. P.: Epithermal Manganese Mineralization, Kimolos Island, South Aegean Volcanic Arc, Greece

Michailidis, K., Trontzios, G., Sofianska, E.: Chemical and mineralogical assessment of clays from Peloponnese (S. Greece) and their evaluation for utilization in ceramics industry

Mposkos, E., Baziotis, I.: Study of the metamorphic evolution of a carbonate - bearing metaperidotite from the Sidironero Complex (Central Rhodope, Greece) using P-T and $\mathrm{P}(\mathrm{T})-\mathrm{X}_{\mathrm{CO}_{2}}$ Pseudosections

Papadopoulos, A., Christofides, G., Papastefanou, C., Koroneos, A., Stoulos, S.: Radioactivity of granitic rocks from Northern Greece

Persianis, D., Katsikis, J., Karageorgiou, D.E.: The genetic hypothesis of the uraniferus mineralization, Eastern Chalkidiki (Northern Greece)

Ploumis, P., Chatzipanagis, I.: Geological, petrological and tectonic features characterizing the commerciality of the marbles of Southern Vermion Mountain

Rigopoulos, I., Tsikoura, B., Pomonis, P., Karipi, S., Hatzipanagiotou, K.: Quantitative analysis of Asbestos fibres in ophiolitic rocks used as aggregates and hazard risk assessment for human health

Solomonidou, A., Dominic Fortes, A., Kyriakopoulos, K.: Modelling of volcanic eruptions on Titan

Stamatakis, M., Stamatakis, G.: The use of diatomaceous rocks of Greek origin as absorbents of olive-oil wastes

Theodosoglou, E., Koroneos, A., Soldatos, T., Zorba, T., Paraskevopoulos, K.M.: Comparative Fourier Transform infrared and X-Ray powder diffraction analysis of naturally occurred K-feldspars

Tzamos, E., Filippidis, A., Kantiranis, N., Sikalidis, C., Tsirambides, A., Papastergios, G., Vogiatzis, D.: Uptake ability of zeolitic rock from South Xerovouni, Avdella, Evros, Hellas

Vasilatos, Ch., Vlachou-Tsipoura, M., Stamatakis, M.G.: On the occurrence of a volcanic ash layer in the Xylokastro Area, North Peloponnesus, Greece: Mineralogy and geochemistry

Voudouris, P., Magganas, A., Kati, M., Gerogianni, N., Kastanioti, G., Sakelaris, G.:

Mineralogical contraints to the formation of vein-type zeolites from Kizari area,

Thrace Northern Greece 
